American Journal of Agricultural and Biological Sciences 5 (4): 430-435, 2010

ISSN 1557-4989

(C) 2010 Science Publications

\title{
Chitinolytic Bacteria Isolated from Chili Rhizosphere: Chitinase Characterization and Its Application as Biocontrol for Whitefly (Bemisia tabaci Genn.)
}

\author{
${ }^{1}$ Nisa Rachmania Mubarik, ${ }^{1}$ Irni Mahagiani, ${ }^{1}$ Amaryllis Anindyaputri, \\ ${ }^{2}$ Sugeng Santoso and ${ }^{1}$ Iman Rusmana \\ ${ }^{1}$ Department of Biology, Faculty of Mathematics and Natural Sciences, \\ Bogor Agricultural University, Jalan Agatis, Dermaga, Bogor 16628, Indonesia \\ ${ }^{2}$ Department of Plant Protection, Faculty of Agricultural, \\ Bogor Agricultural University, Dermaga, Bogor 16628, Indonesia
}

\begin{abstract}
Problem statement: Chitin, a common constituent of insect exoskeleton, could be hydrolyzed by chitinase. The research was conducted to screen chitinolytic rhizobacteria isolated from rhizosphere of chilli pepper and to determine their chitinase activity in degrading chitin of whitefly, Bemisia tabaci Genn. (Hemiptera: Aleyrodidae). Whitefly is recognized as an important pest on many crops including chilli pepper. Approach: Screening and molecular identification based on 16S rRNA sequence of chitinolytic isolates, chitinase productions, measurement of chitinase activity, characterization of chitinase and effect of the chitinase treatment on whitefly were studied. Results: A total of 25 isolates of rhizobacteria formed a clear zone on solid chitin media. Two isolates, i.e., I.5 and I.21 isolates had the highest chitinolytic index. Based on sequence of 16S rRNA gene, the isolates of I.5 and I.21 were identified as Bacillus sp. and Bacillus cereus, respectively. The highest chitinolytic index and specific activity of I.5 isolate was 0.94 and $0.11 \mathrm{U} \mathrm{mg}^{-1}$ proteins, respectively. Maximum production of $\mathrm{I} .5$ chitinase was occured after $36 \mathrm{~h}$ cultivation at $30^{\circ} \mathrm{C}$ and $\mathrm{pH} \mathrm{7.0.} \mathrm{The} \mathrm{highest}$ chitinolytic index and specific activity of I.21isolate was 0.75 and $0.114 \mathrm{U} \mathrm{mg}^{-1}$ proteins, respectively. Maximum production of $\mathrm{I} .21$ chitinase was occured after $36 \mathrm{~h}$ cultivation at $55^{\circ} \mathrm{C}$ and $\mathrm{pH} 7.0$. Cell culture and crude enzyme of the isolates were tested on chitin of B. tabaci and the effect was observed using a microscope and sterile water was used as a negative control. Hydrolytic observation showed that crude enzyme of I.21 isolate could degrade chitin of B. tabaci exoskeleton and the activity was better than that of I.5 isolate. Conclusion: Chitinase produced by Bacillus cereus I.21 strain has potential application as biocontrol agents for B. tabaci.
\end{abstract}

Key words: Rhizobacteria, chitinase, biocontrol, Bemisia tabaci Genn

\section{INTRODUCTION}

Root colonizing bacteria (rhizobacteria) that exert beneficial effects on plant development via direct or indirect mechanisms have been defined as Plant Growth Promoting Rhizobacteria (PGPR). Application of PGPR may become a promising biocontrol agent for plan diseases. Large scale application of PGPR to crop as inoculants will substantially reduce the use of chemical fertilizers and pesticides, which often pollute the environment (Bloemberg and Lugtenberg, 2001).

The whitefly, Bemisia tabaci Genn., (Hemiptera: Aleyrodidae) is an important pest of many crops. It attacks more than 500 plant species belong to 63 plant families. The insect is a vector of plant viruses member of Geminivirus group (Damayanti et al., 2007). In the past decade, whitefly-transmitted plant viruses have increased in prevalence and distribution (Damayanti et al., 2007). The impact has been devastating with yield losses ranging from $20-10 \%$, depending upon the crop, season and prevalence of the whitefly. Some diseases associated with the whitefly are lettuce necrotic yellows, irregular ripening of tomato, silver leaf of squash, cotton leaf curl, tobacco leaf curl and cassava mosaic.

Chitin, a homo-polymer of N-acetyl-Dglucosamine residues linked by $\beta-1,4$ bonds, is the

Corresponding Author: Nisa Rachmania Mubarik, Department of Biology, Faculty of Mathematics and Natural Sciences, Bogor Agricultural University, Jalan Agatis, Dermaga, Bogor 16628, Indonesia Tel/Fax: +62-251-8622633 
most abundant renewable natural resource after cellulose. It is widely distributed in nature as an integument of insects and crustaceans and as a cell wall component of fungi and algae (Toharisman et al., 2005). In insects, chitin is not only synthesized by ectoderm cells of the epidermis, foregut, hindgut, trachea and salivary glands, but also by endoderm cells of the mid-gut

Chitinases \{poly [1, 4-(N-acetyl- $\beta$-glucosaminide)] glycanohydrolase; EC 3.2.1.14\} are a group of enzymes that able to degrade chitin directly into low-molecular weight products. Since chitin-degrading enzymes can be used to convert chitin-containing raw material into biotechnologically utilizable components, they are significant interest of chemical and pharmaceutical industries. Moreover, chitinase may be applied as insecticides and fungicides to control pests and fungal pathogens of plants respectively (Merzendorfer and Zimoch, 2003).

The objectives of this research were to screen potential PGPR from pepper rhizosphere which produce extracellular chitinase and to use the enzyme for controlling whitefly, Bemisia tabaci Genn. as an important pest on many crops.

\section{MATERIALS AND METHODS}

Bacterial isolates: As many as 25 PGPR isolates used in this research were isolated from pepper rhizosphere (Damayanti et al., 2007). The isolates were collected at IPB Culture Collection, Department of Biology, Faculty of Mathematics and Natural Sciences, Bogor Agricultural University, Indonesia.

Screening and selection of chitinolytic activity: The PGPR isolates were grown in chitin agar. The media contained of $1 \%$ colloidal chitin, $0.01 \% \mathrm{MgSO}_{4} .7 \mathrm{H}_{2} \mathrm{O}$, $0.01 \% \mathrm{~K}_{2} \mathrm{HPO}_{4}, 0.05 \%$ yeast extract, $0.7 \%\left(\mathrm{NH}_{4}\right)_{2} \mathrm{SO}_{4}$, $0.1 \% \mathrm{NaCl}$ and $1.5 \%$ bacto agar. Then the cultures were incubated at $37^{\circ} \mathrm{C}$ for $48 \mathrm{~h}$. The isolates possessing chitinolytic activity which perform a clear zone were then selected. The screening was conducted based on chitinolytic index that was defined as a ratio of a clear zone and colony diameter. Morphological characteristics of bacterial colony and Gram stain of the isolates were also observed.

Bacterial identification: Identification of the isolates was determined based on sequence of $16 \mathrm{~S}$ rRNA gene. The DNA genome of isolates was extracted according to the procedures of Sambrook (2001). Amplification of the gene was carried out by PCR using Marchesi specific primer $63 \mathrm{f}$ (5'-CAG GCC TAA CAC ATG
CAA GTC-3') and 1387r (5' - GGG CGG WGT GTA CAA GGC-3') (Wahyudi et al., 2010). The PCR condition was set up 30 cycles (Baharuddin et al., 2010) with pre-denaturing step at $94^{\circ} \mathrm{C}$ for $2 \mathrm{~min}$, denaturing at $92^{\circ} \mathrm{C}$ for $30 \mathrm{sec}$, annealing at $55^{\circ} \mathrm{C}$ for 30 sec, polymerization at $75^{\circ} \mathrm{C}$ for $1 \mathrm{~min}$ and post $\mathrm{PCR}$ at $75^{\circ} \mathrm{C}$ for $5 \mathrm{~min}$. The PCR products, approximately 1300 $\mathrm{bp}$, were purified and sequenced using ABI 310 (Perkin Elmer, USA). Alignment of the 16S-rRNA sequences was conducted by using the BLASTN program from NCBI web site (http://www.ncbi.nlm.nih.gov). Construction of Neighbor Joining Tree and bootstrap analysis of 1000 re-sampling were conducted using a software of MEGA 4.0 (Tamura et al., 2007)

Growth condition and chitinase production: A number of $10^{8}$ cells $\mathrm{mL}^{-1}$ were inoculated to $100 \mathrm{~mL}$ chitin medium containing $0.3 \%$ colloidal chitin, $0.01 \%$ $\mathrm{MgSO}_{4} .7 \mathrm{H}_{2} \mathrm{O}, 0.01 \% \quad \mathrm{~K}_{2} \mathrm{HPO}_{4}, 0.05 \%$ yeast extract, $0.7 \%\left(\mathrm{NH}_{4}\right)_{2} \mathrm{SO}_{4}$ and $0.1 \% \mathrm{NaCl}$. The cultures were incubated at $37^{\circ} \mathrm{C}$ for $72 \mathrm{~h}$ on a shaker incubator set up at $120 \mathrm{rpm}$. The cultures were then centrifuged at 8400 $\mathrm{g}$ for $10 \mathrm{~min}$ to obtain the crude extract of extracellular chitinase enzyme.

Measurement of chitinase activity and protein concentration: Chitinase activity was measured by a modified of Spindler method (Toharisman et al. 2005). The crude extract of extracellular enzyme $150 \mu \mathrm{L}$ was added to $300 \mu \mathrm{L} 0.3 \%$ colloidal chitin and $150 \mu \mathrm{L} 10.1$ $\mathrm{M}$ phosphate buffer at $37^{\circ} \mathrm{C}, \mathrm{pH} 7.0,120 \mathrm{rpm}$. The mixture was incubated at $55^{\circ} \mathrm{C}$ for $30 \mathrm{~min}$. After centrifugation at $8400 \mathrm{~g}$ for $5 \mathrm{~min}$, the filtrate was added to $500 \mu \mathrm{L}$ distillated water and $1000 \mu \mathrm{L}$ Schales reagent and the mixture was boiled at $100^{\circ} \mathrm{C}$. Enzyme activity was determined by measuring absorbance at $420 \mathrm{~nm}$. One unit of enzyme activity was defined as amount of enzyme which released $1 \mu$ mol of reduced sugar (N-acetyl glucosamine) per minute. Protein concentration was determined by the method of Bradford (1976) using bovine serum albumin as a standard.

Characterization of chitinase activity: Chitinase activity was measured at range of $\mathrm{pH} 4$ up to 10 . Effect of temperature on chitinase activity was determined at temperature range of $25^{\circ} \mathrm{C}$ up to $60^{\circ} \mathrm{C}$ with $5^{\circ} \mathrm{C}$ interval fromtheoptimumpHobtainedfromtheprevious experiment.

Effect of crude chinitase on whitefly exoskeleton: Crude chitinase of the selected isolates were tested to whitefly exoskeleton at room temperature $\left( \pm 30^{\circ} \mathrm{C}\right)$. The enzymes were produced at $37^{\circ} \mathrm{C}$ and $\mathrm{pH}$ 7.0. Twelve 
mature whiteflies were kept in a jar and each insect was dropped with $20 \mu \mathrm{L}$ crude chitinases. The ability of the chitinase to hydrolyze exoskeleton of whitefly was observed after 3 days of treatment using whole mount method. Treated whiteflies were firstly fixed with $70 \%$ ethanol $\mathrm{f}$ or $24 \mathrm{~h}$ and dehydrated with ethanol $90 \%$ for 10 min. Then the whiteflies were dropped with clove oil for 15 min and cleared using xylol. Each whitefly was put on an object glass, covered and tightened with synthetic resin Entellanßembedding agent. Chitin thickness was observed under a light microscope at 100 times magnification. The observation was conducted in two replicates.

\section{RESULTS}

Properties of chitinolytic isolates: There were 25 PGPR isolates performing a clear zone around their colony on chitin agar (Table 1). Formation of a clear zone indicated that the isolates produced extracellular chitinase. Isolates of I.5 and I.21 showed the highest chitinolytic index i.e., 0.94 and 0.75 , respectively. The isolates are Gram-positive and rod shaped bacteria.

Identification of chitinolytic isolates: Amplification of $16 \mathrm{~S}$ rRNA gene resulted a specific DNA fragment of approximately $1300 \mathrm{bp}$. DNA sequence analysis of the PCR products using the BlastN revealed that I.5 isolate had the closest similarity to Bacillus sp. BBT91 (88\% similarity) and I.21 isolate had the closest similarity to Bacillus cereus BSA 37 (93\% similarity).

Table 1: Properties of chitinase producing PGPR

\begin{tabular}{llllll} 
& & & Colony & \\
Isolate & index & the cell & stain & Shape & Color \\
\hline I.10 & 0.02 & Rod & + & Round & White \\
I.20 & 0.01 & Rod & + & Round & White \\
I.30 & 0.17 & Rod & + & Round & White \\
I.40 & 0.06 & Ovoid & - & Round & White \\
I.50 & 0.94 & Rod & + & Round & White \\
I.80 & 0.05 & Ovoid & - & Round & White \\
I.14 & 0.04 & Rod & - & Round & Brownish \\
I.15 & 0.08 & Rod & - & Round & Brownish \\
I.21 & 0.75 & Rod & + & Round & White \\
I.25 & 0.10 & Rod & + & Round & Transparent \\
I.26 & 0.11 & Rod & - & Round & Yellow \\
I.28 & 0.10 & Rod & - & Round & Brownish \\
I.33 & 0.10 & Rod & + & Round & White \\
I.34 & 0.10 & Rod & - & Round & White \\
II.70 & 0.05 & Rod & - & Round & Yellow \\
II.80 & 0.06 & Rod & - & Round & Orange \\
II.10 & 0.10 & Rod & - & Round & White \\
II.11 & 0.10 & Coccus & - & Round & White \\
II.12 & 0.03 & Rod & - & Round & White \\
II.13 & 0.51 & Rod & + & Round & White \\
II.14 & 0.10 & Rod & + & Round & White \\
II.15 & 0.10 & Rod & - & Round & Yellow \\
II.16 & 0.03 & Coccus & - & Round & Yellow \\
II.17 & 0.02 & Rod & - & Round & Orange \\
II.34 & 0.10 & Rod & - & Round & Yellow \\
\hline & & & & &
\end{tabular}

This result indicated that 1.5 isolate was Bacillus sp. I.5 and I.21 isolate was B. cereus I.21. Phylogenetic tree based on partial sequences of $16 \mathrm{~S}$ rRNA gene showed the cluster relationship of the isolates among their group (Fig. 1).

Growth and chitinase production of the chitinolytic isolates: Two selected isolates were grown in liquid chitin media $\left(\mathrm{pH} \mathrm{7.0)}\right.$ at $37^{\circ} \mathrm{C}$. The growth rate of $\mathrm{I.5}$ isolate was ascended from $0-12 \mathrm{~h}$ of incubation and then the growth was relatively stable up to $72 \mathrm{~h}$ of incubation (Fig. 2a). Similarly the growth rate of I.21 isolate was ascended from $0-12 \mathrm{~h}$ of incubation, however it was descended afterwards (Fig. 2b).

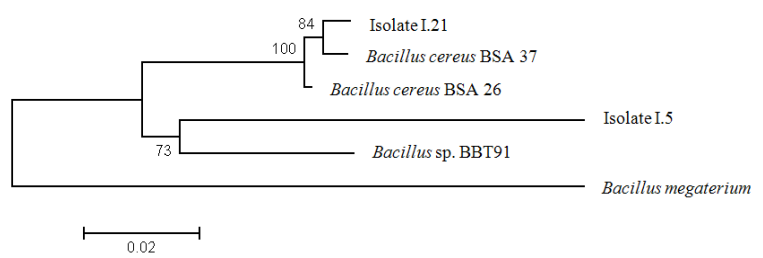

Fig. 1: Dendogram of the chitinolitic isolates based on partial sequences of $16 \mathrm{~S}$ rRNA gene with reference strains. The scale bar corresponds to 0.02 substitutions per nucleotide position

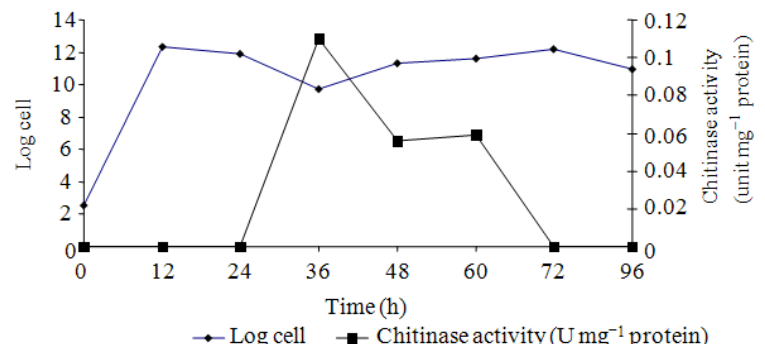

(a)

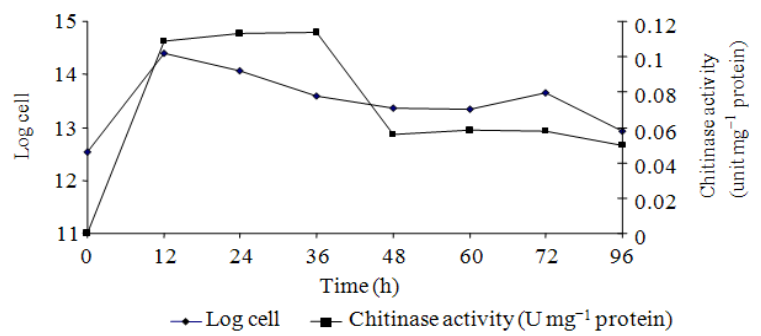

(b)

Fig. 2: Growth and chitinase activity of the selescted isolates; (a) I.5 isolate and (b) I.21 isolates. Growth of cell $(\bullet)$ and enzyme production $(\bullet)$ were measured at $37^{\circ} \mathrm{C}$ and $\mathrm{pH} 7.0$ 


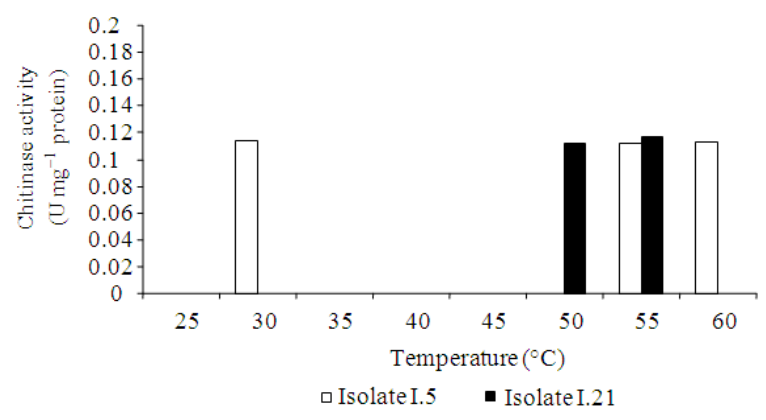

Fig. 3: Effect of temperature on chitinase activity of I.5 and I.21 isolates at $\mathrm{pH} 7.0$

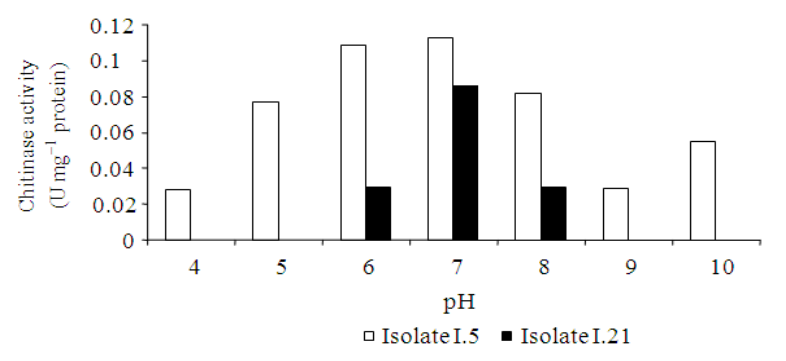

Fig. 4: Effect of pH on chitinase activity of I.5 and I.21 isolates. The activity was measured at $55^{\circ} \mathrm{C}$

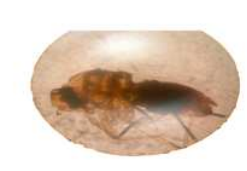

$0.5 \mathrm{~mm}$

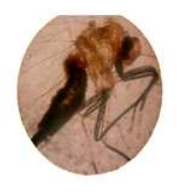

(b)

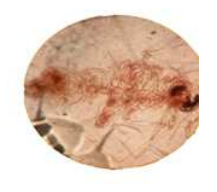

(c)
Fig. 5: Whitefly exoskeleton after 3 days treatment of control (a), crude chitinase enzyme of I.5 isolate (b) and crude chitinase enzyme of I.21 isolate (c) at room temperature. Microscope observation was done at 100 times magnification

Chitinase produced by I.5 isolate was detected starting $36 \mathrm{~h}$ of incubation, however the activity was not detected after $60 \mathrm{~h}$ of incubation (Fig. 2a). The highest chitinase activity was found at $36 \mathrm{~h}$ of incubation. Furthermore chitinase production of I.21 isolate was detected starting $12 \mathrm{~h}$ of incubation and it was ascended up to $36 \mathrm{~h}$ of incubation. And afterwards it was descended and still detected up to $96 \mathrm{~h}$ of incubation. The highest chitinase production of I.21 isolate was also found at $36 \mathrm{~h}$ of incubation (Fig. 2b).

Characterization of chitinase activity: Optimum temperature for chitinase maximum activity of I.5 isolate was at 55 and $60^{\circ} \mathrm{C}$. The activity was not detected (zero activity) at temperature between 30$50^{\circ} \mathrm{C}$. However, isolate of I.21 showed chitinase activity at 50 and $55^{\circ} \mathrm{C}$ (Fig. 3). Regarding optimum $\mathrm{pH}$ of the enzyme activity, it was shown that both isolates had the maximum activity at $\mathrm{pH}$ 7.0. There was no chitinase activity of $\mathrm{I} .21$ isolate at $\mathrm{pH}$ either lower than pH 5.0 or higher than pH 8 (Fig. 4).

Whitefly chitin hydrolysis: About $20 \mu \mathrm{L}$ crude enzyme $\left(0.08 \mathrm{U} \mathrm{mg}^{-1}\right.$ protein) of each chitinase was used to hydrolyze whitefly exoskeleton. Microscopic observation showed that whitefly exoskeleton were thinned out. Chitinases of the isolates made the exoskeleton getting thinner after 3 days treatment. Treatment of chitinase showed significantly different than that of control on whitefly exoskeleton. The treated exoskeletons were become more transparent than that of control particularly on the effect of I.21 crude chitinase (Fig. 5).

\section{DISCUSSION}

Based on sequence of the 16S rRNA gene, I.5 isolate was similar to Bacillus sp. and I.21 isolate was similar to B. cereus. Shanmugaiah et al. (2008) reported that among the 39 chitinolytic bacteria which were isolated from rice rhizosphere, only 11 isolates produced zone of clearance over $0.5 \mathrm{~cm}$ on chitin colloidal agar. Chitinase production was reported in different species of Bacillus such as B. amyloliquefaciens (Wang et al., 2002), B. cereus (Huang et al., 2005), B. circulans (Chen et al., 2004), B. licheniformis (Waldeck et al., 2006), B. megaterium (Donderski and Brzezinska, 2005), B. stearothermophilus (Sakai et al., 1994), B. subtilis (Wang et al., 2006), B. thuringiensis sub sp. aizawai (De la Vega et al., 2006), $B$. thuringiensis sub sp. kurstaki (Driss et al., 2005).

Isolate of I.5 and I.21 produced extracellular chitinase hydrolyzing a substrate such as chitin colloidal. The highest specific chitinase activity was found at stationary phase when the cells density began to decrease, it was at $36 \mathrm{~h}$ of incubation. After incubated $48 \mathrm{~h}$ the activity was started to decrease and yet I.5 isolate showed no chitinase activity after $72 \mathrm{~h}$ of incubation. Isolate of I.21 showed chitinase activity at 50 and $55^{\circ} \mathrm{C}$. Chitinase of I.5 isolate had the highest activity at $30^{\circ} \mathrm{C}$ and also had the activity at 55 and $60^{\circ} \mathrm{C}$. There were no chitinase activity between 30 and $50^{\circ} \mathrm{C}$. It was assumed that more than one chitinase at the crude enzymes of I.5 isolate, which had optimum activity at 30 and $55^{\circ} \mathrm{C}$, respectively. Chitinases have been isolated from variety of bacteria including 
Bacillus spp. and some of them are reported to produce multiple forms of chitinases with different molecular weight (Shanmugaiah et al., 2008).

Enzyme activity was also affected by $\mathrm{pH}$. Chitinase of I.5 isolate showed activity at $\mathrm{pH} \mathrm{5-8}$ and the highest activity were found at $\mathrm{pH} 7$. Isolate of I.21 only had activity in between $\mathrm{pH} 6$ up to 8 and the optimum activity at $\mathrm{pH}$ 7. Chitinase activity of bacteria were generally optimum at low $\mathrm{pH}$, but some bacteria also had optimum $\mathrm{pH}$ at neutral $\mathrm{pH}$ (Toharisman et al., 2005).

This research analyzed the ability of cell culture and chitinases of I.5 and I.21 isolates in degrading exoskeleton of whitefly (Bemisia tabaci). Damaging level of exoskeleton caused by the treatment was observed. Chitinase treatment made it possible to hydrolyze chitin of the whitefly exoskeleton. Insect exoskeleton shown dark color was degraded by the enzyme becoming more transparent. Objects with higher transparency showed higher quantity of hydrolyzed chitin. I.21 chitinase showed more effective to hydrolized exoskeleton of whitefly than I.5. Chitinase produced by isolate was a potential bacterium to be improved and used as a biocontrol agent for pest insects such as whitefly. Application of chitinase also can be done by spraying it directly to the plants. Leaves and fruits of chitinase sprayed strawberry showed no presence of any insects nor pathogenic fungi (Koga, 2005). Combination between chitinase and $\sigma$-toxin of $B$. thuringiensis were found more effective in killing pest insects (Patil et al., 2000). Spreading of chitin to a plant was also an alternative application to control pest insects, because it will induce chitinolytic bacteria to secrete chitinase (Metcalfe et al., 2002).

\section{CONCLUSION}

Bacillus sp. I.5 and Bacillus cereus I.21 isolates produced chitinase optimum at $\mathrm{pH}$ 7.0. Chitinase of I.21 isolate was more effective to hydrolyze exoskeleton of whitefly (Bemisia tabaci) than that of I.5 isolate. Chitinase is a potential biocontrol agent against whitefly.

\section{REFERENCES}

Baharuddin, A.S., M.N.A. Razak, S.H. Lim, M.N. Ahmad, S. Abd-Aziz et al., 2010. Isolation and characterization of thermophilic cellulaseproducing bacteria from empty fruit bunches-palm oil mill effluent compost. Am. J. Applied Sci., 7: 56-62.

http://www.scipub.org/fulltext/ajas/ajas715662.pdf
Bloemberg, G.V. and B.J.J. Lugtenberg, 2001. Molecular basis of plant growth promotion and biocontrol by rhizobacteria. Curr. Opin. Plant Biol., 4: 343-350. DOI: 10.1016/S1369-5266(00)00183-7

Bradford, M.M., 1976. A rapid and sensitive method for the quantitation of microgram quantities of protein utilizing the principle of protein-dye binding. Anal. Biochem., 72: 248-254. DOI: 10.1016/0003-2697(76)90527-3

Chen, C.Y., Y.H. Wang and C.J. Huang, 2004. Enhancement of the antifungal activity of Bacillus subtilis F29-3 by the chitinase encoded by Bacillus circulans chiA gene. Can. J. Microbiol., 50: 451-454. PMID: 15284891

Damayanti, T.A., H. Pardede and N.R. Mubarik, 2007. Utilization of root-colonizing bacteria to protect hot-pepper against Tobacco Mosaic Tobamovirus. Hayati J. Biosci., 14: 105-109. http://www.ijonline.net/index.php/HAYATI/article /view/157

De la Vega, L.M., J.E. Barboza-Corona, M.G. AguilarUscanga and M. Ramirez-Lepe, 2006. Purification and characterization of an exochitinase from Bacillus thuringiensis subsp. aizawai and its action against phytopathogenic fungi. Can. J. Microbiol., 52: 651-657. DOI: 10.1139/W06-019

Donderski, W. and M.S. Brzezinska, 2005. The influence of heavy metals on the activity of chitinases produced by planktonic, benthic and epiphytic bacteria. Polish J. Environ. Stud., 14: 851-859. http://www.pjoes.com/pdf/14.6/851859.pdf

Driss, F., M. Kallassy_Awad, N. Zouari and S. Jaoua, 2005. Molecular characterization of a novel chitinase from Bacillus thuringiensis subsp. kurstaki. J. Applied Microbiol., 99: 945-53. DOI: 10.1111/j.1365-2672.2005.02639.x

Huang, C.J., T.K. Wang, S.C. Chung and C.Y. Chen, 2005. Identification of an antifungal chitinase from a potential biocontrol agent, Bacillus cereus 28-9. J. Biochem. Mol. Biol., 38: 82-88. PMID: 15715951

Koga, D., 2005. Application of chitinase in agriculture. J. Met. Mater. Miner., 15: 33-36.

Merzendorfer, H. and L. Zimoch, 2003. Chitin metabolism in insects: Structure, function and regulation of chitin synthetases and chitinases. J. Exp. Biol. 206: 4393-4412. DOI: 10.1242/jeb.00709

Metcalfe, A.C., M. Krsek, G.W. Gooday, J. Prosser and E.M.H. Wellington, 2002. Molecular analysis of a bacterial chitinolytic community in an upland pasture. Applied Environ. Microbiol., 68: 5042-5050. DOI: 10.1128/AEM.68.10.5042-5050.2002 
Patil, R.S., V. Ghormade and M.V. Desphande, 2000. Chitinolytic enzymes: An exploration. Enz. Microb. Technol., 26: 473-483. DOI: 10.1016/S0141-0229(00)00134-4

Sakai, K., M. Narihara, Y. Kasama, M. Wakayama and M. Moriguchi, 1994. Purification and characterization of thermostable beta-Nacetylhexosaminidase of Bacillus stearothermophilus $\mathrm{CH}-4$ isolated from chitincontaining compost. Applied Environ. Microbiol., 60: 2911-2915. PMCID: PMC201742

Sambrook, J., 2001. Molecular Cloning: A Laboratory Manual. 3rd Edn., Gold Spring Harbor Laboratory, New York, ISBN: 0879695773, pp: 999.

Shanmugaiah, V., N. Mathivanan, N. Balasubramanian and P.T. Manoharan, 2008. Optimization of cultural conditions for production of chitinase by Bacillus laterosporous MML2270 isolated from rice rhizosphere soil. Afr. J. Biotechnol., 15: 2562-2568.

Tamura, K., J. Dudley, M. Nei and S. Kumar, 2007. MEGA4: Molecular Evolutionary Genetics Analysis (MEGA) software version 4.0. J. Mol. Biol. Evol., 24: 1596-1599. PMID: 17488738

Toharisman, A., M.T. Suhartono, M. Spindler-Barth, J.K. Hwang and Y.R. Pyun, 2005. Purification and characterization of thermostable chitinase from Bacillus licheniformis Mb-2. World J. Microbiol. Biotechnol., 21: 733-738. DOI: 10.1007/s11274004-4797-1
Wahyudi, A.T., B.J. Prasojo and N.R. Mubarik NR., 2010. Diversity of antifungal compoundsproducing Bacillus spp. isolated from rhizosphere of soybean plant based on ARDRA and 16S rRNA. Hayati J. Biosci., 17: 145-150. http://journal.ipb.ac.id/index.php/hayati/article/vie wArticle/1692

Waldeck, J., G. Daum, B. Bisping and F. Meinhardt, 2006. Isolation and molecular characterization of chitinase deficient Bacillus licheniformis strains capable of deproteinization of shrimp shell waste to obtain highly viscous chitin. Applied Environ. Microbiol., 72: 7879-7885. DOI: 10.1128/AEM.00938-06

Wang, S.L., I.L. Shih, W.W. Liang and C.H. Wang, 2002. Purification and characterization of two antifungal chitinases extracellularly produced by Bacillus amyloliquefaciens V656 in a shrimp and crab shell powder medium. J. Agric. Food Chem., 50: 2241-2248. PMID: 11929278

Wang, S.L., T.Y. Lin, Y.H. Yen, H.F. Liao and Y.J. Chen, 2006. Bioconversion of shellfish chitin wastes for the production of Bacillus subtilis W118 chitinase. Carbohydr. Res., 341: 2507-2515. PMID: 16920090 